\title{
The Lipid A from the Haloalkaliphilic Bacterium Salinivibrio sharmensis Strain $\mathbf{B A G}^{\mathrm{T}}$
}

\section{Sara Carillo ${ }^{1}$, Giuseppina Pieretti ${ }^{1}$, Buko Lindner ${ }^{2}$, Ida Romano ${ }^{3}$, Barbara Nicolaus ${ }^{3}$, Rosa Lanzetta ${ }^{1}$, Michelangelo Parrilli ${ }^{1}$ and Maria Michela Corsaro ${ }^{1, *}$}

1 Department of Chemical Sciences, University of Naples "Federico II", Complesso Universitario Monte S. Angelo, Via Cintia 4, 80126 Naples, Italy; E-Mails: sara.carillo2@unina.it (S.C.); gpieretti@unina.it(G.P.); lanzetta@unina.it (R.L.); parrilli@unina.it (M.P.)

2 Division of Immunochemistry, Research Center Borstel, Leibniz-Center for Medicine and Biosciences, Parkallee 10, D-23845 Borstel, Germany; E-Mail: blindner@fz-borstel.de

3 CNR Institute of Biomolecular Chemistry (ICB-CNR), National Research Council (CNR), Via Campi Flegrei 34, 80078 Pozzuoli, Italy; E-Mails: ida.romano@icb.cnr.it (I.R.); bnicolaus@icb.cnr.it (B.N.)

* Author to whom correspondence should be addressed; E-Mail: corsaro@unina.it; Tel.: +39-081-674149; Fax: +39-081-674393.

Received: 11 December 2012; in revised form: 9 January 2013 / Accepted: 11 January 2013 / Published: 21 January 2013

Abstract: Lipid A is a major constituent of the lipopolysaccharides (or endotoxins), which are complex amphiphilic macromolecules anchored in the outer membrane of Gram-negative bacteria. The glycolipid lipid A is known to possess the minimal chemical structure for LPSs endotoxic activity, able to cause septic shock. Lipid A isolated from extremophiles is interesting, since very few cases of pathogenic bacteria have been found among these microorganisms. In some cases their lipid A has shown to have an antagonist activity, i.e., it is able to interact with the immune system of the host without triggering a proinflammatory response by blocking binding of substances that could elicit such a response. However, the relationship between the structure and the activity of these molecules is far from being completely clear. A deeper knowledge of the lipid A chemical structure can help the understanding of these mechanisms. In this manuscript, we present our work on the complete structural characterization of the lipid A obtained from the lipopolysaccharides (LPS) of the haloalkaliphilic bacterium Salinivibrio sharmensis. Lipid A was obtained from the purified LPS by mild acid hydrolysis. The lipid A, which contains different number of fatty acids residues, and its partially deacylated derivatives 
were completely characterized by means of electrospray ionization Fourier transform ion cyclotron (ESI FT-ICR) mass spectrometry and chemical analysis.

Keywords: endotoxin; lipid A; mass spectrometry; Salinivibrio sharmensis; haloalkaliphile

\section{Introduction}

Saline environments, for example deep sea or saline lakes, are the perfect habitat for extremophilic microorganisms such as haloalkaliphiles. In these hard life conditions (high $\mathrm{pH}$ values, saturated salt solutions), these bacteria are forced to modify the structure and the composition of their cell; in fact, they undergo strong osmotic stress that is overcome by accumulating osmolytes or by maintaining a cytoplasmic salt concentration $(\mathrm{KCl})$ close to that of the surrounding medium [1,2]. As a consequence, proteins from halophiles are constituted by negatively charged amino acid residues on their surface [3], and membrane phospholipids become more anionic [4,5].

The outer cellular membrane of Gram-negative bacteria is mainly composed of lipopolysaccharides (LPS), amphiphilic macromolecules anchored in the phospholipid bilayer with their lipid part. The LPS amphiphilic nature is defined by their three different covalently linked regions. These are: The hydrophilic polysaccharide portion composed of the $O$-specific antigen, which glycosylates the core oligosaccharide. The latter glycosylates the lipophilic glycolipid portion of lipid A. In particular, the lipid $\mathrm{A}$ is an immunomodulatory molecule and is recognized by different classes of receptors on both mammalian and plant cells [6]. It has a conserved architecture consisting of a $\beta$-D-GlcN'-(1'-6)-D-GlcN disaccharide (Glc $p \mathrm{~N}$ is 2-amino-2-deoxy-D-glucopyranose) carrying an $\alpha$-glycosidic-bound phosphate group at position $\mathrm{C}$-1 of the proximal reducing glucosamine residue $(\mathrm{Glc} p \mathrm{~N} \mathrm{I})$ and an ester-bound one at position 4' of the distal, non-reducing end glucosamine residue $(\mathrm{Glc} p \mathrm{~N}$ II). Both amino sugar units are substituted with a number of ester- and amide-linked fatty acids. These fatty acids are peculiar because they bear a 3-OH group, which, in turn, can be esterified by other fatty acids residues [7]. The lipid A fraction is intrinsically heterogeneous due to the different degree of phosphorylation and acylation, the distribution and the type of acyl residues. The toxicity of the LPSs depends strongly on the lipid A structure, and is also influenced by the core region [8-10].

Among the extremophiles very few cases of pathogenic bacteria have been found. To the best of our knowledge the lipopolysaccharides from the haloalkaliphilic pathogenic bacteria Halomonas stevensii were the only ones, which have been characterized [11] so far. In some other cases, endotoxins isolated from extremophilic bacteria have been found to exert an antagonist activity, i.e., they are able to interact with the immune system of the host without triggering a proinflammatory response blocking the binding of substances that could elicit such response [12]. However, the relationship between structure and activity of these molecules is by far not completely clear. A deeper knowledge of the lipid A chemical structure can help the understanding of these mechanisms.

From the saline lake in Ras Mohammed Park (Egypt), a novel haloalkaliphilic, facultative anaerobic and Gram-negative microorganism (designated strain $\mathrm{BAG}^{\mathrm{T}}$ ) has recently been recovered. It was identified as a novel species of the Salinivibrio genus, and named Salinivibrio sharmensis [13]. 
In this manuscript, we present the complete structural characterization of the lipid A obtained from its LPS. To obtain the lipid A, dried cells were extracted by using the phenol-chloroform-petroleum ether (PCP) method and the LPS was purified and hydrolyzed under mild acidic conditions. The lipid A and its partially deacylated derivatives were completely characterized by means of electrospray ionization Fourier transform ion cyclotron (ESI FT-ICR) mass spectrometry and chemical analysis in order to reveal the nature and the distribution of fatty acids linked to the disaccharidic glucosamine backbone.

\section{Results and Discussion}

\subsection{Isolation of Lipid A and Its Compositional Analysis}

Dried cells from haloalkaliphilic bacterium Salinivibrio sharmensis $\mathrm{BAG}^{\mathrm{T}}$ were extracted by the PCP method [14]. The obtained lipopolysaccharidic fraction was hydrolyzed under mild acidic condition, with $5 \%$ acetic acid. The gas chromatography mass spectrography (GC-MS) analysis of the fatty acids methyl esters derivative, obtained after the LPS methanolysis, showed the presence of 3-hydroxy-dodecanoic $[\mathrm{C} 12: 0(3-\mathrm{OH})]$ and 3-hydroxy-tetradecanoic acids $[\mathrm{C} 14: 0(3-\mathrm{OH})]$, as the most abundant species, together with dodecanoic $(\mathrm{C} 12: 0)$, tetradecanoic $(\mathrm{C} 14: 0)$ and hexadecenoic $(\mathrm{C} 16: 1)$ acids.

\subsection{ESI FT-ICR Mass Spectrometric Analysis of Lipid A}

Lipid A was analyzed by ESI FT-ICR mass spectrometry. The charge deconvoluted negative ions ESI FT-ICR mass spectrum showed the presence of nine signals (M1-M9, Figure 1, Table 1) corresponding to a number of glycoforms differing in their acylation as well as their phosphorylation degree. In particular, they ranged from hexa-acylated to di-acylated glycoforms and, except for M9, were mono or bis-phosphorylated.

Figure 1. The charge deconvoluted negative ion electrospray ionization Fourier transform ion cyclotron (ESI FT-ICR) mass spectrum of the lipid A from Salinivibrio sharmensis strain $\mathrm{BAG}^{\mathrm{T}}$.

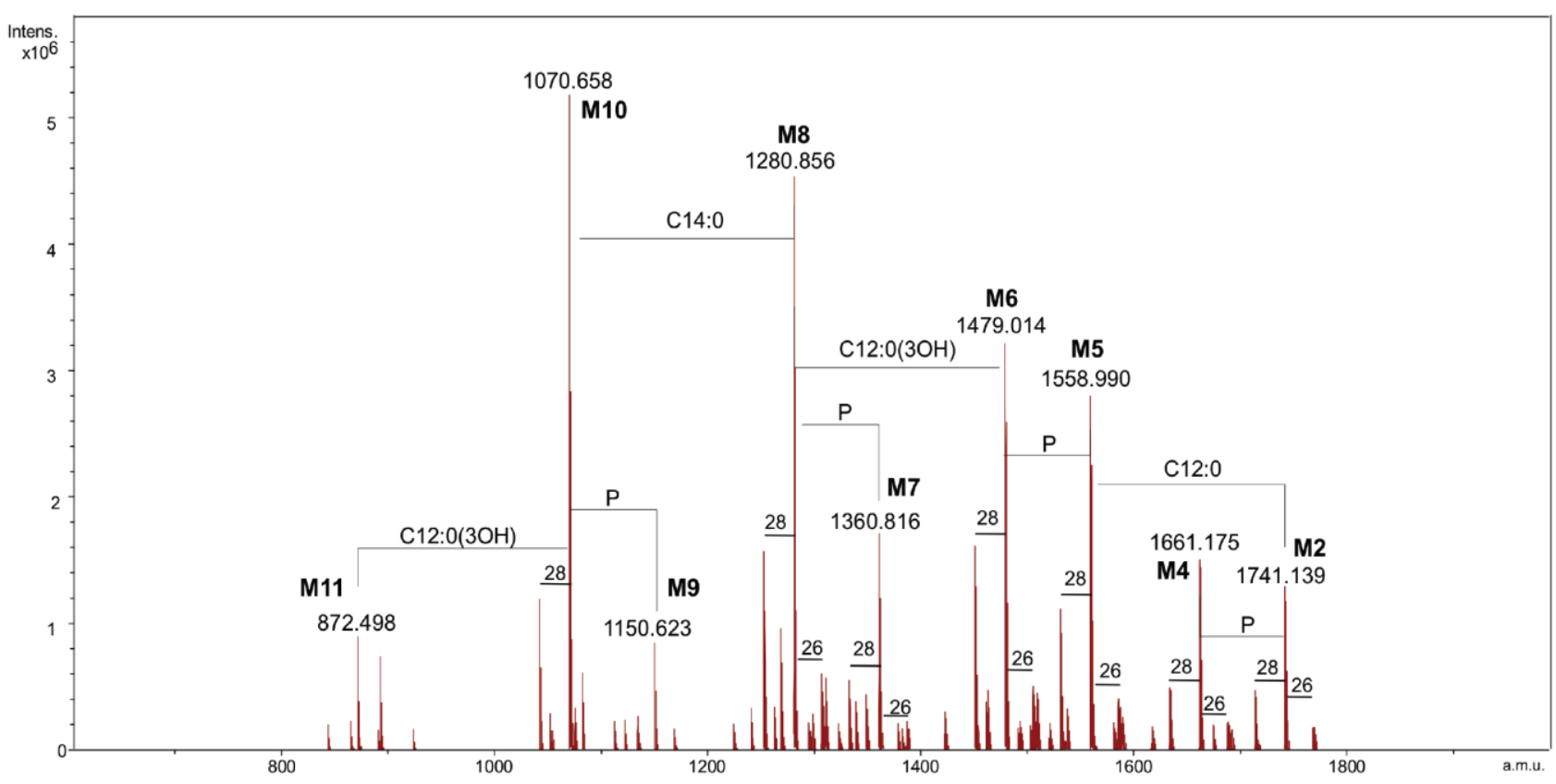


Table 1. Composition of the main species present in the charge deconvoluted negative ions ESI FT-ICR mass spectrum of the lipid A from Salinivibrio sharmensis strain BAG ${ }^{\mathrm{T}}$.

\begin{tabular}{cccc}
\hline Species & $\mathbf{M}_{\text {obs }}$ & $\mathbf{M}_{\text {acc }}$ & Composition \\
\hline M1 & 1741.14 & 1741.17 & $\mathrm{GlcN}_{2} \mathrm{P}_{2}[\mathrm{C} 12: 0(3-\mathrm{OH})]_{2}[\mathrm{C} 14: 0(3-\mathrm{OH})]_{2}(\mathrm{C} 12: 0)(\mathrm{C} 14: 0)$ \\
M2 & 1661.18 & 1661.21 & $\mathrm{GlcN}_{2} \mathrm{P}[\mathrm{C} 12: 0(3-\mathrm{OH})]_{2}[\mathrm{C} 14: 0(3-\mathrm{OH})]_{2}(\mathrm{C} 12: 0)(\mathrm{C} 14: 0)$ \\
M3 & 1558.99 & 1559.00 & $\mathrm{GlcN}_{2} \mathrm{P}_{2}[\mathrm{C} 12: 0(3-\mathrm{OH})]_{2}[\mathrm{C} 14: 0(3-\mathrm{OH})]_{2}(\mathrm{C} 14: 0)$ \\
M4 & 1479.01 & 1479.04 & $\mathrm{GlcN}_{2} \mathrm{P}[\mathrm{C} 12: 0(3-\mathrm{OH})]_{2}[\mathrm{C} 14: 0(3-\mathrm{OH})]_{2}(\mathrm{C} 14: 0)$ \\
M5 & 1360.82 & 1360.84 & $\mathrm{GlcN}_{2} \mathrm{P}_{2}[\mathrm{C} 12: 0(3-\mathrm{OH})][\mathrm{C} 14: 0(3-\mathrm{OH})]_{2}(\mathrm{C} 14: 0)$ \\
M6 & 1280.86 & 1280.87 & $\mathrm{GlcN}_{2} \mathrm{P}[\mathrm{C} 12: 0(3-\mathrm{OH})][\mathrm{C} 14: 0(3-\mathrm{OH})]_{2}(\mathrm{C} 14: 0)$ \\
M7 & 1150.62 & 1150.64 & $\mathrm{GlcN}_{2} \mathrm{P}_{2}[\mathrm{C} 12: 0(3-\mathrm{OH})][\mathrm{C} 14: 0(3-\mathrm{OH})]_{2}$ \\
M8 & 1070.66 & 1070.67 & $\mathrm{GlcN}_{2} \mathrm{P}[\mathrm{C} 12: 0(3-\mathrm{OH})][\mathrm{C} 14: 0(3-\mathrm{OH})]_{2}$ \\
M9 & 872.50 & 872.51 & $\mathrm{GlcN}_{2} \mathrm{P}[\mathrm{C} 14: 0(3-\mathrm{OH})]_{2}$ \\
\hline
\end{tabular}

In particular M1, M3, M5 and M7 corresponded to the bis-phosphorylated glycoforms. The following composition was attributed to the species M1, with the mass $1741.14 \mathrm{Da}$, $\mathrm{GlcN}_{2} \mathrm{P}_{2}[\mathrm{C} 12: 0(3-\mathrm{OH})]_{2}[\mathrm{C} 14: 0(3-\mathrm{OH})]_{2}(\mathrm{C} 12: 0)(\mathrm{C} 14: 0)$ (calculated molecular mass: $\left.1741.17 \mathrm{Da}\right)$. Species M3 was identified as penta-acylated lipid A since it carries no C12:0 fatty acid, while the M5 species was missing a C12:0 and 3-hydroxy dodecanoic acid. The tri-acylated species M7 contained only one 3-hydroxy dodecanoic and two 3-hydroxy tetradecanoic acids. Finally M9 was the only di-acylated species corresponding to the following composition $\mathrm{GlcN}_{2} \mathrm{P}[\mathrm{C} 14: 0(3-\mathrm{OH})]_{2}$. Less abundant species, due to the replacement of the $\mathrm{C} 14: 0$ with a $\mathrm{C} 16: 1(+26 \mathrm{u})$ or a $\mathrm{C} 12: 0(-28 \mathrm{u})$ fatty acid, were also present. In order to obtain the detailed information on the distribution of fatty acids on the disaccharidic backbone, MS and MS/MS spectra in the positive ion mode were generated.

The FT-ICR-MS (positive ion mode) of lipid A showed the presence of the adduct ion $\left[\mathrm{M}+\mathrm{Et}_{3} \mathrm{~N}+\mathrm{H}\right]^{+}$at $m / z$ 1843.31, which corresponded to the hexa-acylated, bis-phosphorylated glycoform (calculated molecular mass: $m / z$ 1843.303). The MS/MS spectrum of this species, obtained by infrared multiphoton dissociation (IRMPD) (see experimental section), displayed a $\mathrm{B}^{+}$ fragment ion $[15,16]$ at $\mathrm{m} / \mathrm{z} 1058.76$, to which the following composition was attributed GlcNP[C12:0(3-OH)][C14:0(3-OH)](C12:0)(C14:0) (calculated mass $\mathrm{m} / z$ 1058.77). These results proved that both the secondary fatty acids $(\mathrm{C} 12: 0$ and $\mathrm{C} 14: 0)$ were linked to the distal non-reducing end glucosamine.

\subsection{Analysis of $\mathrm{NH}_{4} \mathrm{OH}$ Product}

By treating the sample with $\mathrm{NH}_{4} \mathrm{OH}$ [17], the lipid A was deprived of primary $O$-linked fatty acids. The product was analyzed again in the positive ion mode. The mass spectrum revealed the presence of four main signals corresponding to $[\mathrm{M}+\mathrm{H}]^{+}$adducts with one or two $\mathrm{Et}_{3} \mathrm{~N}$ molecules, followed by the signals of the corresponding monophosphorylated species at $80 \mathrm{u}$ lower (N1-N6, Figure 2, Table 2). 
Figure 2. The charge deconvoluted positive ion ESI FT-ICR mass spectrum of the $\mathrm{NH}_{4} \mathrm{OH}$ product from the lipid A of Salinivibrio sharmensis strain $\mathrm{BAG}^{\mathrm{T}}$.

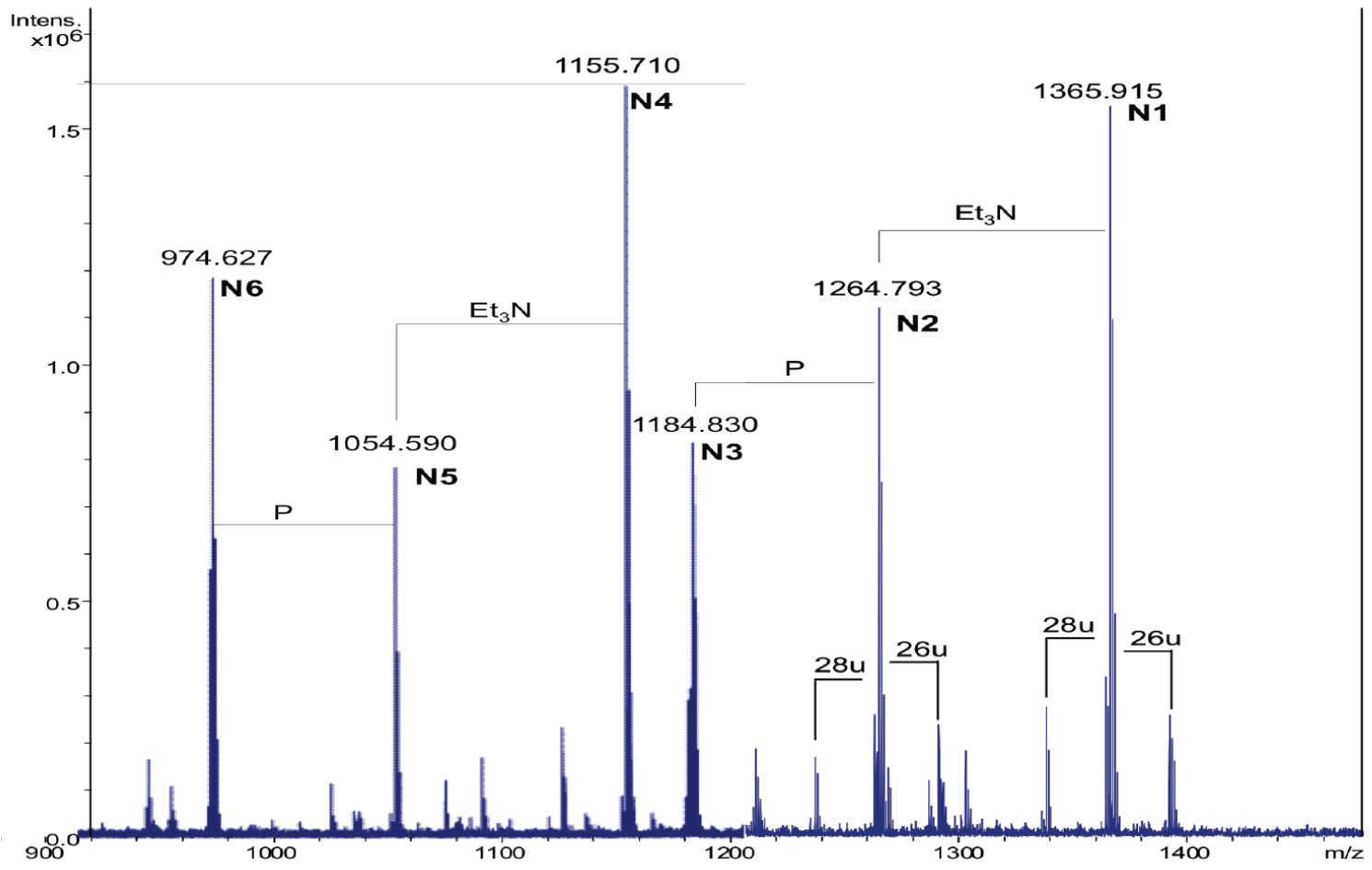

Table 2. Composition of the main species present in the positive ions ESI FT-ICR mass spectrum of the $\mathrm{NH}_{4} \mathrm{OH}$ product of the lipid A from $S$. sharmensis strain $\mathrm{BAG}^{\mathrm{T}}$.

\begin{tabular}{cccc}
\hline Species & Observed $\boldsymbol{m} / \boldsymbol{z}$ & Calculated $\boldsymbol{m} / \boldsymbol{z}$ & Composition \\
\hline $\mathbf{N 1}$ & $1365.91^{\mathrm{a}}$ & 1365.92 & $\mathrm{GlcN}_{2} \mathrm{P}_{2}[\mathrm{C} 14: 0(3-\mathrm{OH})]_{2}(\mathrm{C} 14: 0)$ \\
$\mathbf{N 2}$ & $1264.79^{\mathrm{b}}$ & 1264.80 & $\mathrm{GlcN}_{2} \mathrm{P}_{2}[\mathrm{C} 14: 0(3-\mathrm{OH})]_{2}(\mathrm{C} 14: 0)$ \\
$\mathbf{N 3}$ & $1184.83^{\mathrm{b}}$ & 1184.84 & $\mathrm{GlcN}_{2} \mathrm{P}[\mathrm{C} 14: 0(3-\mathrm{OH})]_{2}(\mathrm{C} 14: 0)$ \\
N4 & $1155.71^{\mathrm{a}}$ & 1155.72 & $\mathrm{GlcN}_{2} \mathrm{P}_{2}[\mathrm{C} 14: 0(3-\mathrm{OH})]_{2}$ \\
N5 & $1054.59^{\mathrm{b}}$ & 1054.60 & $\mathrm{GlcN}_{2} \mathrm{P}_{2}[\mathrm{C} 14: 0(3-\mathrm{OH})]_{2}$ \\
N6 & $974.63^{\mathrm{b}}$ & 974.64 & $\mathrm{GlcN}_{2} \mathrm{P}[\mathrm{C} 14: 0(3-\mathrm{OH})]_{2}$ \\
\hline
\end{tabular}

a This signal corresponds to the adduct $\left[\mathrm{M}+2 \mathrm{Et}_{3} \mathrm{~N}+\mathrm{H}^{+} ;{ }^{\mathrm{b}}\right.$ This signal corresponds to the adduct $\left[\mathrm{M}+\mathrm{Et}_{3} \mathrm{~N}+\mathrm{H}\right]^{+}$.

The $\left[\mathrm{M}+2 \mathrm{Et}_{3} \mathrm{~N}+\mathrm{H}\right]^{+}$adduct ion at $1365.91 \mathrm{~m} / z$ (N1) was selected for fragmentation. The MS/MS spectrum showed the presence of a $\mathrm{B}^{+}$fragment ion at $m / z 678.4$ (GlcNP[C14:0(3-OH)]C14:0, calculated $m / z 678.3$, Figure 3a), thus revealing that C14:0 was linked as acyloxyamide to the GlcN II. As a consequence, C12:0 resulted to be linked as acyloxyacyl to the GlcN II. In Figure 2, starting from the N1 signal, a species at $26 \mathrm{u}$ higher masses was found $(\mathrm{m} / \mathrm{z} 1391.90)$, which corresponded to the replacement of the C14:0 with $\mathrm{C} 16: 1$, as already found.

The MS/MS spectrum of the signal at $m / z 1391.9$ (Figure 3b) displayed the presence of a $\mathrm{B}^{+}$ fragment ion at $m / z 704.4$ confirming that $\mathrm{C} 16: 1$ occupies the same position of $\mathrm{C} 14: 0$. The MS/MS spectrum of $\mathbf{N} 3$ showed the presence of a $\mathrm{B}^{+}$fragment ion at $678.4 \mathrm{~m} / \mathrm{z}$, the same as obtained by $\mathbf{N 1}$ fragmentation (data not shown). This pointed out that the phosphate group on the proximal glucosamine was not stoichiometric. The lack of the phosphate group was a consequence of the $5 \%$ acetic acid hydrolysis. In fact, in a recently published paper [18], where the oligosaccharidic 
portion of the LPS from Salinivibrio sharmensis was characterized after mild and strong alkaline treatment of the LPS, the phopshorylation was stoichiometric. On the basis of all the data obtained from the mass spectra as well as from the chemical analysis, the structure of the lipid A from the $S$. sharmensis strain $\mathrm{BAG}^{\mathrm{T}}$ is depicted in Scheme 1.

Figure 3. ESI FT-ICR tandem mass spectrum infrared multiphoton dissociation (IRMPD). (a) Product ion scan of the isolated precursor ion $1365.9 \mathrm{~m} / \mathrm{z}$. (b) Product ion scan of the isolated precursor ion $1391.9 \mathrm{~m} / \mathrm{z}$.

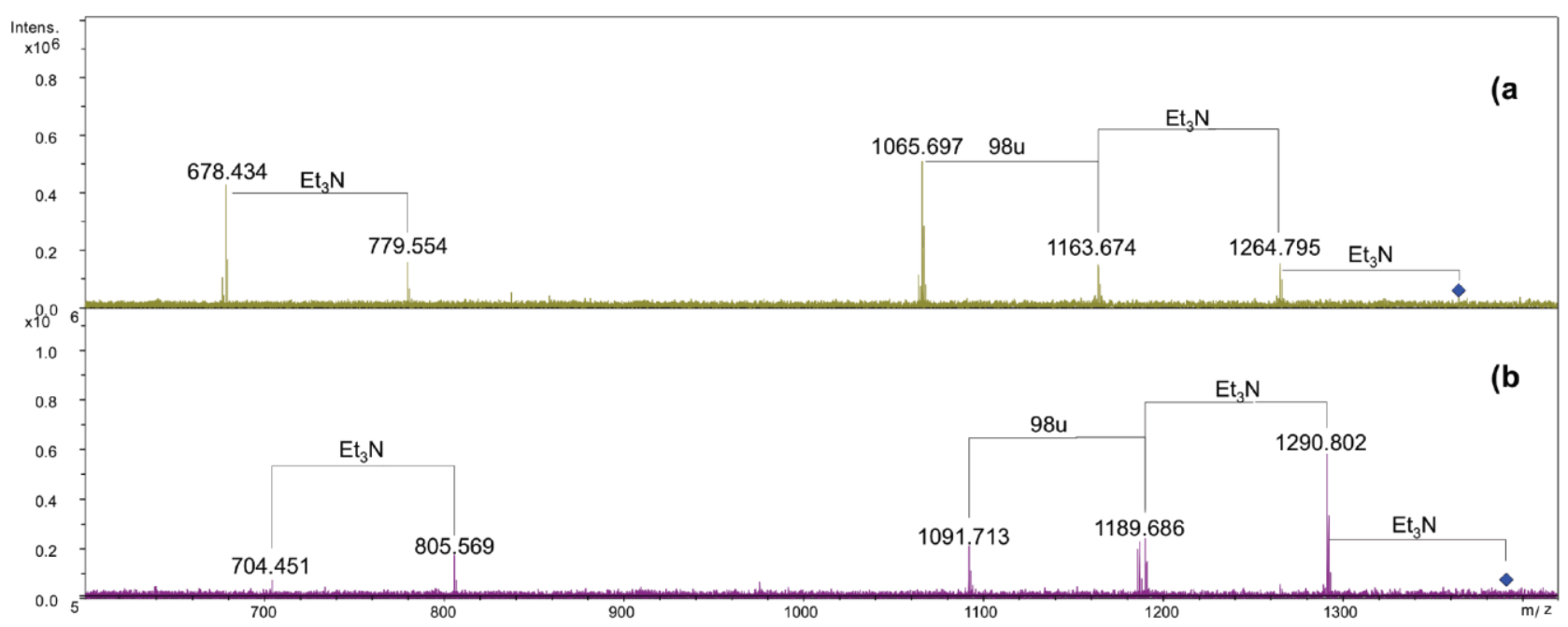

Scheme 1. Structure of the Lipid A from Salinivibrio sharmensis strain BAG ${ }^{\mathrm{T}}$.

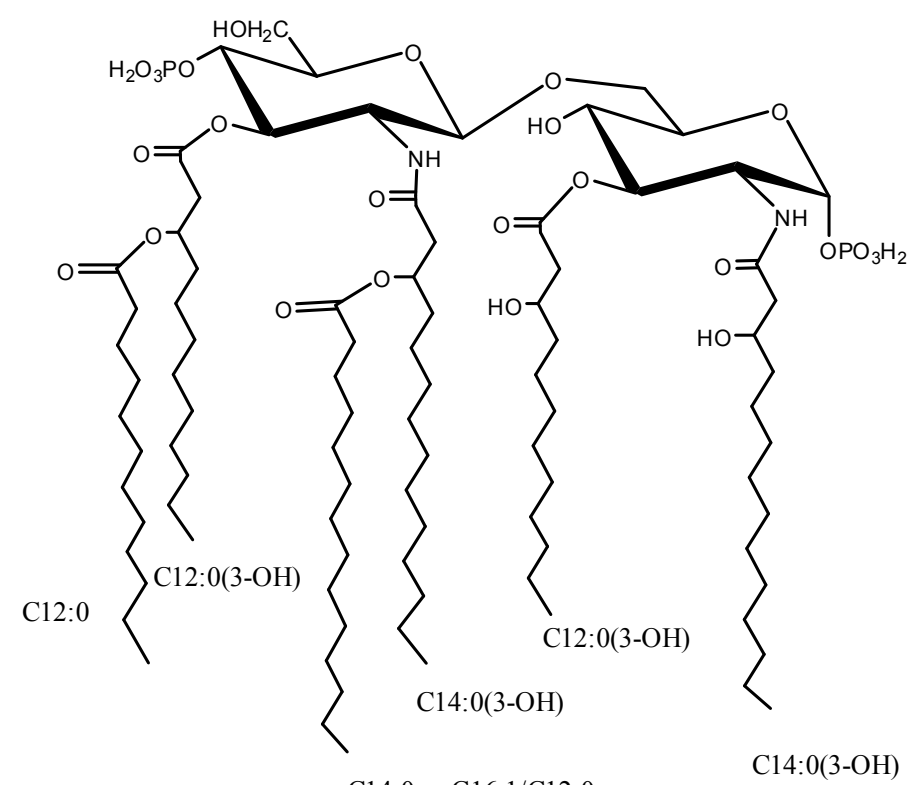

$\mathrm{C} 14: 0$ or $\mathrm{C} 16: 1 / \mathrm{C} 12: 0$

C14:0(3-OH)

\section{Experimental Section}

\subsection{Isolation of the LPS}

S. sharmensis strain $\mathrm{BAG}^{\mathrm{T}}\left(=\mathrm{ATCC}\right.$ BAA $\left.-1319^{\mathrm{T}}=\mathrm{DSM} 18182^{\mathrm{T}}\right)$, isolated from samples collected in a small permanent saline lake in Ras Mohammed Park, located at Sharm el-Sheikh (Egypt) [13], 
was grown at $35{ }^{\circ} \mathrm{C}$ and at $\mathrm{pH} 9.0$, using a medium containing the following components $(\mathrm{g} / \mathrm{L})$ : yeast extract 10.0, $\mathrm{NaCl} 100.0, \mathrm{Na}_{3}$-citrate 3.0, $\mathrm{Na}_{2} \mathrm{CO}_{3}$ 3.0, $\mathrm{KCl} 2.0, \mathrm{MgSO}_{4} \cdot 7 \mathrm{H}_{2} \mathrm{O}$ 1.0, $\mathrm{MnCl}_{2} \cdot 4 \mathrm{H}_{2} \mathrm{O}$ $0.00036, \mathrm{FeSO}_{4} 0.05$ ( $\mathrm{NaCl}$ and $\mathrm{Na}_{2} \mathrm{CO}_{3}$ were autoclaved separately). The medium was autoclaved for $20 \mathrm{~min}$ at $121{ }^{\circ} \mathrm{C}$. The inoculum was prepared using a dilution of 1:50 v/v. Bacterial growth was directly monitored in an UV/Vis spectrophotometer DU 730 (Beckman Coulter) by utilizing the change in optical density at $540 \mathrm{~nm}$. After incubation for $24 \mathrm{~h}$ at an absorbance of 2.0, the cells were collected by centrifugation at $10,000 \times \mathrm{g}$ and lyophilized. Dried bacteria cells $(7 \mathrm{~g})$ were extracted by PCP method [14], obtaining $103 \mathrm{mg}$ of LPS (yield 1.5\% of dried cells).

\subsection{Mild Acid Hydrolysis of the LPS}

The LPS $(30 \mathrm{mg})$ was incubated with $5 \%$ aqueous $\mathrm{CH}_{3} \mathrm{COOH}(3 \mathrm{~mL})$ for $4 \mathrm{~h}$ at $100{ }^{\circ} \mathrm{C}$. The sample was then centrifuged at $10,000 \times \mathrm{g}$ for $15 \mathrm{~min}$ and two fractions were recovered: the lipid A (5.3 $\mathrm{mg})$ and the saccharidic portion $(22.7 \mathrm{mg})$.

\subsection{Chemical Analysis}

A sample of the lipid A fraction $(0.5 \mathrm{mg})$ was dried and methanolyzed, as already described elsewhere [12]. Briefly, $1 \mathrm{~mL}$ of $1 \mathrm{M} \mathrm{HCl} / \mathrm{CH}_{3} \mathrm{OH}$ was added to the sample and the reaction was carried out at $80{ }^{\circ} \mathrm{C}$ for $20 \mathrm{~h}$. The crude mixture was extracted twice with hexane. The methanol layer, containing the methyl glycosides, was dried and the residue acetylated by treating with pyridine $(200 \mu \mathrm{L})$ and acetic anhydride $(100 \mu \mathrm{L})$ at $100^{\circ} \mathrm{C}$ for $30 \mathrm{~min}$. Then both the hexane layer, containing the fatty acids as methyl esters derivatives, and the acetylated methyl glycosides were analyzed by GC-MS. The analyses were performed on a Agilent Technologies gas chromatograph 6850A equipped with a mass selective detector $5973 \mathrm{~N}$ and a Zebron ZB-5 capillary column (Phenomenex, $30 \mathrm{~m} \times 0.25 \mathrm{~mm}$ i.d., flow rate $1 \mathrm{~mL} / \mathrm{min}$, He as carrier gas). The following temperature program was used for lipid analysis $-140{ }^{\circ} \mathrm{C}$ for $3 \mathrm{~min}, 140{ }^{\circ} \mathrm{C} \rightarrow 280{ }^{\circ} \mathrm{C}$ at $10^{\circ} \mathrm{C} / \mathrm{min}$. Acetylated methyl glycosides were analyzed with the following temperature programs $-150{ }^{\circ} \mathrm{C}$ for $3 \mathrm{~min}, 150{ }^{\circ} \mathrm{C} \rightarrow 240{ }^{\circ} \mathrm{C}$ at $3{ }^{\circ} \mathrm{C} / \mathrm{min}$.

\section{4. $\mathrm{NH}_{4} \mathrm{OH}$ Hydrolysis of Lipid $\mathrm{A}$}

Lipid A $(0.6 \mathrm{mg})$ was incubated with conc. $\mathrm{NH}_{4} \mathrm{OH}(100 \mu \mathrm{L})$ as reported [17]. The sample was dried and analyzed by ESI FT-ICR mass spectrometry.

\subsection{ESI FT-ICR Mass Spectrometry}

Electrospray ionization Fourier transform ion cyclotron (ESI FT-ICR) mass spectrometry was performed in the negative and positive ion mode using an APEX QE (Bruker Daltonics) equipped with a 7 Tesla actively shielded magnet. For the negative-ion spectra, samples $(\sim 10 \mu \mathrm{g})$ were dissolved in a 50:50:0.001 ( $/ \mathrm{v} / \mathrm{v})$ mixture of 2-propanol, water, and triethylamine ( $\mathrm{pH} 8.5)$. The samples were sprayed at a flow rate of $2 \mu \mathrm{L} \mathrm{m^{-1 }}$. Capillary entrance voltage was set to $3.8 \mathrm{kV}$ and drying gas temperature to $200{ }^{\circ} \mathrm{C}$. The instrument was externally calibrated with appropriate standards. The 
negative ion mass spectra were charge deconvoluted, and the mass numbers given refer to the monoisotopic mass of the neutral molecules.

The MS/MS lipid species were analyzed in the positive ion mode using a 50:50:0.03 (v/v/v) mixture of 2-propanol, water, and $30 \mathrm{mM}$ ammonium acetate $(\mathrm{pH} \mathrm{4.5).} \mathrm{Small} \mathrm{amounts} \mathrm{of} \mathrm{triethylamine} \mathrm{were}$ added to generate triethylamine adduct ions, which are favorable as precursor ions for MS/MS [16]. Precursor ions were isolated in the ICR-cell and then fragmented by infrared multiphoton dissociation (IRMPD). For this, the unfocused beam of a 35-watt, $\mathrm{CO}_{2}$ laser (Synrad) was directed through the center of the trap. The duration of laser irradiation was adapted for optimal fragmentation and varied between 50 and $200 \mathrm{~ms}$, and fragment ions were detected after a delay of $0.5 \mathrm{~ms}$.

\section{Conclusions}

In the organization of the microbial membrane, lipopolysaccharides occupy the outer leaflet, and therefore they are the first to come in contact with the external habitat. This is the reason why they are thought to play a key role in the adaptation mechanisms of extremophilic microorganisms. In particular, the nature and distribution of fatty acids belonging to membrane phospholipids and lipid A may change according to the external environment.

The peculiar acylation of the lipid A of the haloalkalophilic Salinivibrio sharmensis, ranging from di- to hexa-acyl structures, might be connected with the supramolecular structure of its membrane which helps the bacterium to survive in an extreme habitat such as a saline lake.

Depending on the nature and distribution of fatty acyl chains, lipid A may induce a pro-inflammatory or an anti-inflammatory response after interaction with host cells receptors. In particular, lipid A molecules isolated from extremophilic non-pathogenic microorganisms potentially have interesting biological activities and their structure elucidation is the mandatory starting point for the understanding of both adaptation and host-bacterium recognition mechanisms.

In this work we established the structure of S. sharmensis lipid A. It is composed of a family of molecules with different acylation patterns; the fatty acid C14:0(3-OH) is always found to be acyloxyamide linked to both glucosamines of the saccharidic backbone, while position 3 and 3' are substituted with $\mathrm{C} 12: 0(3-\mathrm{OH})$. The distribution of secondary acyl chains in the hexa-acyl species is asymmetric $(4+2)$, since $\mathrm{C} 12: 0$ and $\mathrm{C} 14: 0$ are both linked as acyloxyacyl to the primary fatty acids of the distal glucosamine. In addition $\mathrm{C} 14: 0$ can be replaced by $\mathrm{C} 16: 1$ or $\mathrm{C} 12: 0$. The overall fatty acid distribution resembles that of E. coli lipid A [19], even though the chain length of primary $O$-linked fatty acids is different. On the contrary Neisseria meningitidis lipid A [20] shows the same distribution of primary fatty acids, but its hexa-acylated lipid A species displays an overall symmetric $3+3$ fatty acids distribution, since C12:0 secondary fatty acids are linked as acyloxyacyl at position 2 and 2', respectively. N. meningitidis lipid A, is not toxic and shows little agonist behavior [21], it is a good candidate to be used as vaccine adjuvant. On this basis the biological activity of the lipid A from Salinivibrio sharmensis is also worth being investigated. 


\section{References}

1. Galinsky, E.A. Compatible solutes of halophilic eubacteria: Molecular principles, water-solute interaction, stress protection. Experientia 1993, 49, 487-496.

2. Galinsky, E.A.; Trüper, H.G. Microbial behavior in salt-stressed ecosystems. FEMS Microbiol. Rev. 1994, 15, 95-108.

3. Van de Burg, B. Extremophiles as a source for novel enzymes. Curr. Opin. Microbiol. 2003, 6, 213-218.

4. Beales, N. Adaptation of microorganisms to cold temperatures, weak acid preservatives, low $\mathrm{pH}$, and osmotic stress: A review. Comp. Rev. Food Sci. Food Safety 2004, 3, 1-20.

5. Russell, N.J.; Evans, R.I.; ter Steeg, P.F.; Hellemons, J.; Verheul, A.; Abee, T. Membranes as a target for stress adaptation. Int. J. Food Microbiol. 1995, 28, 255-261.

6. Alexander, C.; Zähringer, U. Chemical Structure of Lipid A. The Primary Immunomodulatory Center of Bacterial Lipopolysaccharides. Trends Glycosci. Glycotechnol. 2002, 14, 69-86.

7. Endotoxin in Health and Disease; Brade, H., Opal, S.M., Vogel, S.N., Morrison, D.C., Eds.; Marcel Dekker: New York, NY, USA, 1999; pp. 93-114.

8. Holst, O. The structures of core regions from enterobacterial lipopolysaccharides - an update. FEMS Microbiol. Lett. 2007, 271, 3-11.

9. Izquierdo, L.; Coderch, N.; Piqué, N.; Bedini, E.; Corsaro, M.M.; Merino, S.; Fresno, S.; Tomás, J.M.; Regué, M. The Klebsiella pneumonia wabG gene: Its role in the biosynthesis of the core lipopolysaccharide and virulence. J. Bacteriol. 2003, 185, 7213-7221.

10. Fresno, S.; Jiménez, N.; Izquierdo, L.; Merino, S.; Corsaro, M.M.; de Castro, C.; Parrilli, M.; Naldi, T.; Regué, M.; Tomás, J.M. The ionic interaction of Klebsiella pneumoniae K2 capsule and core lipopolysaccharide. Microbiology 2006, 152, 1807-1818.

11. Pieretti, G.; Carillo, S.; Lindner, B.; Kim, K.K.; Lee, K.C.; Lee, J.S.; Lanzetta, R.; Parrilli, M.; Corsaro, M.M. Characterization of the core oligosaccharide and the O-antigen biological repeating unit from Halomonas stevensii LPS: The first case of O-antigen linked to the inner core. Chem. Eur. J. 2012, 18, 3729-3735.

12. Carillo, S.; Pieretti, G.; Parrilli, E.; Tutino, M.L.; Gemma, S.; Molteni, M.; Lanzetta, R.; Parrilli, M.; Corsaro, M.M. Structural Investigation and Biological Activity of the Lipooligosaccharide from the Psychrophilic Bacterium Pseudoalteromonas haloplanktis TAB 23. Chem. Eur. J. 2011, 17, 7053-7060.

13. Romano, I.; Orlando, P.; Gambacorta, A.; Nicolaus, B.; Dipasquale, L.; Pascual, J.; Giordano, A.; Lama, L. Salinivibrio sharmensis sp. nov., a novel haloalkaliphilic bacterium from a saline lake in Ras Mohammed Park (Egypt). Extremophiles 2011, 15, 213-220.

14. Galanos, C.; Lüderitz, O.; Westphal, O. A new method for the extraction of R lipopolysaccharides. Eur. J. Biochem. 1969, 9, 245-249.

15. Domon, B.; Costello, C.E. A systematic nomenclature for carbohydrate fragmentations in FAB-MS/MS spectra of glycoconjugates. Glycoconj. J. 1988, 5, 397-409.

16. Kondakova, A.; Lindner, B. Structural characterization of complex bacterial glycolipids by Fourier transform mass spectrometry. Eur. J. Mass Spectrom. 2005, 11, 535-546. 
17. Silipo, A.; Lanzetta, R.; Amoresano, A.; Parrilli, M.; Molinaro, A. Ammonium hydroxide hydrolysis: A valuable support in the MALDI-TOF mass spectrometry analysis of Lipid A fatty acid distribution. J. Lipid Res. 2002, 43, 2188-2195.

18. Carillo, S.; Pieretti, G.; Lindner, B.; Romano, I.; Nicolaus, B.; Lanzetta, R.; Parrilli, M.; Corsaro, M.M. Structural characterization of the core oligosaccharide isolated from the lipopolysaccharide of the haloalkaliphilic bacterium Salinivibrio sharmensis strain BAG $^{\mathrm{T}}$. Carbohydr. Res. 2012, doi:10.1016/j.carres.2012.12.013.

19. Holst, O.; Müller-Loennies, S.; Lindner, B.; Brade, H. Chemical structure of the lipid A of Escherichia coli J-5. Eur. J. Biochem. 1993, 214, 695-701.

20. Kulshin, V.A.; Zaehringer, U.; Lindner, B.; Frasch, C.E.; Tsai, C.M.; Dmitriev, B.A.; Rietschel, E.T. Structural characterization of the lipid A component of pathogenic Neisseria meningitidis. J. Bacteriol. 1992, 174, 1793-1800.

21. Zughaier, S.; Steeghs, L.; van der Ley, P.; Stephens, D.S. TLR4-dependent adjuvant activity of Neisseria meningitidis lipid A. Vaccine 2007, 25, 4401-4409.

(C) 2013 by the authors; licensee MDPI, Basel, Switzerland. This article is an open access article distributed under the terms and conditions of the Creative Commons Attribution license (http://creativecommons.org/licenses/by/3.0/). 